\title{
Louse Infestation of the Chiribaya Culture, Southern Peru: Variation in Prevalence by Age and Sex
}

\author{
Karl J Reinhard/ ${ }^{+}$, Jane Buikstra* \\ School of Natural Resource Sciences, University of Nebraska-Lincoln, 214 Bessey Hall, Lincoln, NE 685-0340 USA \\ *Department of Anthropology, University of New Mexico, Albuquerque, New Mexico, USA
}

In order to improve the interpretive potential of archaeoparasitology, it is important to demonstrate that the epidemiology of ancient parasites is comparable to that of modern parasites. Once this is demonstrated, then we can be secure that the evidence of ancient parasitism truly reflects the pathoecology of parasitic disease. Presented here is an analysis of the paleoepidemiology of Pediculus humanus infestation from 146 mummies from the Chiribaya culture 1000-1250 AD of Southern Peru. The study demonstrates the modern parasitological axiom that 10\% of the population harbors $70 \%$ of the parasites holds true for ancient louse infestation. This is the first demonstration of the paleoepidemiology of prehistoric lice infestation.

Key words: Pediculus humanus - pathoecology - paleoepidemiology - archaeoparasitology - Peru

In archaeoparasitology, as with any field of parasitology, interpretive strength is based on reliable analysis of large numbers of observations. For those of us dependent on archaeological excavations, the biggest challenge is obtaining large numbers of observations. Often times factors of preservation, field sampling conditions, and other aspects of archaeology reduce the number of observations to a handful of data points. This in turn limits the strength of interpretations about prehistoric infections, infestations and health.

Dr Jane Buikstra's Programa Contisuyo excavations in the Moquegua Valley of Southern Peru offered the opportunity to collect archaeoparasitology data from a large series of mummies. During dissection of the mummies, we noted the presence of louse nits and eggs in the hair and realized that a survey of the mummies for nits and eggs would provide an unparalleled source of intersite comparative data. We examined 146 mummified or partially mummified individuals from the sites of San Geronimo, Chiribaya Alta, Algodonal, and El Yaral.

\section{MATERIALS AND METHODS}

During the month of August, 1990, we collected data on louse parasitism for every individual that had been dissected to date and could be located in the Ilo Programa Contisuyo Laboratory from the sites of Chiriabya Alta, Algodonal, El Yaral and San Geronimo. One problem that we encountered was that many of the mummies had already been dissected and cleaned. Therefore, it was not possible to quantify all of the infestations. Of 164 individuals from all sites, we located 146 and examined them for lice nits/eggs. Not every specimen was acceptable for study. Some individuals had hair or scalp tissue that was

${ }^{+}$Corresponding author. Fax: $+402-472.6858$. E-mail: kreinhard1@unl.edu

Received 26 August 2002

Accepted 25 November 2002 too poorly preserved for analysis. These individuals were so noted in the field to prevent their inclusion in later comparative analysis (Table I). Because examination of hair did not require dissection, it was possible to analyze several mummies from El Yaral as they were unwrapped.

The technique improvised for this study was based on the examination of the hair bases at the scalp (referred to subsequently as scalp measurements) and hair shafts located several inches away from the scalp (referred to subsequently as hair measurements). The scalps were examined to identify areas of maximum nit density and minimum nit density. Maximum density usually was on the parietal area, and in the area above and behind the ears. A $2 \times 2 \mathrm{~cm}$ square was cut into a cardboard strip. The cardboard strip was then placed on the identified areas and all nits/eggs within the $2 \times 2 \mathrm{~cm}$ area were counted. Three observations were taken for each area of scalp minimum density and scalp maximum density (Table II). The hair was also examined for areas of minimum and maximum nit/egg density. An optimal distance of 5 inches from the scalp was preferred, but in some cases, observations were made 4-6 cm from the scalp when the hair was not well preserved at $10 \mathrm{~cm}$. The cardboard strip was then placed on the identified areas and all nits/eggs within the $2 \times 2 \mathrm{~cm}$ area were counted.

\section{RESULTS}

Of 146 individuals examined, not all were sufficiently preserved for analysis (Table I). In some cases, the scalp was poorly preserved but the hair was well preserved. More rarely, the hair was poorly preserved or absent, but the scalp was well preserved. A few individuals exhibited poor preservation of scalp and hair. The San Geronimo individuals especially exhibited poor preservation of the hair and scalp tissue. Consequently, this site had to be dropped from comparative study because of poor overall preservation.

Generally, individuals who had lice nits/eggs on the scalp had louse nits/eggs on the hair. From all 4 sites, 75 mummies had both scalp and hair present. Twenty (27\%) individuals had nits/eggs on the hair immediately adja- 
TABLE I

Provenience and condition of individuals examined for louse infestation. Asterisks indicate individuals whose scalp or hair was too poorly preserved for study. Chiribaya Culture mummies, Peru

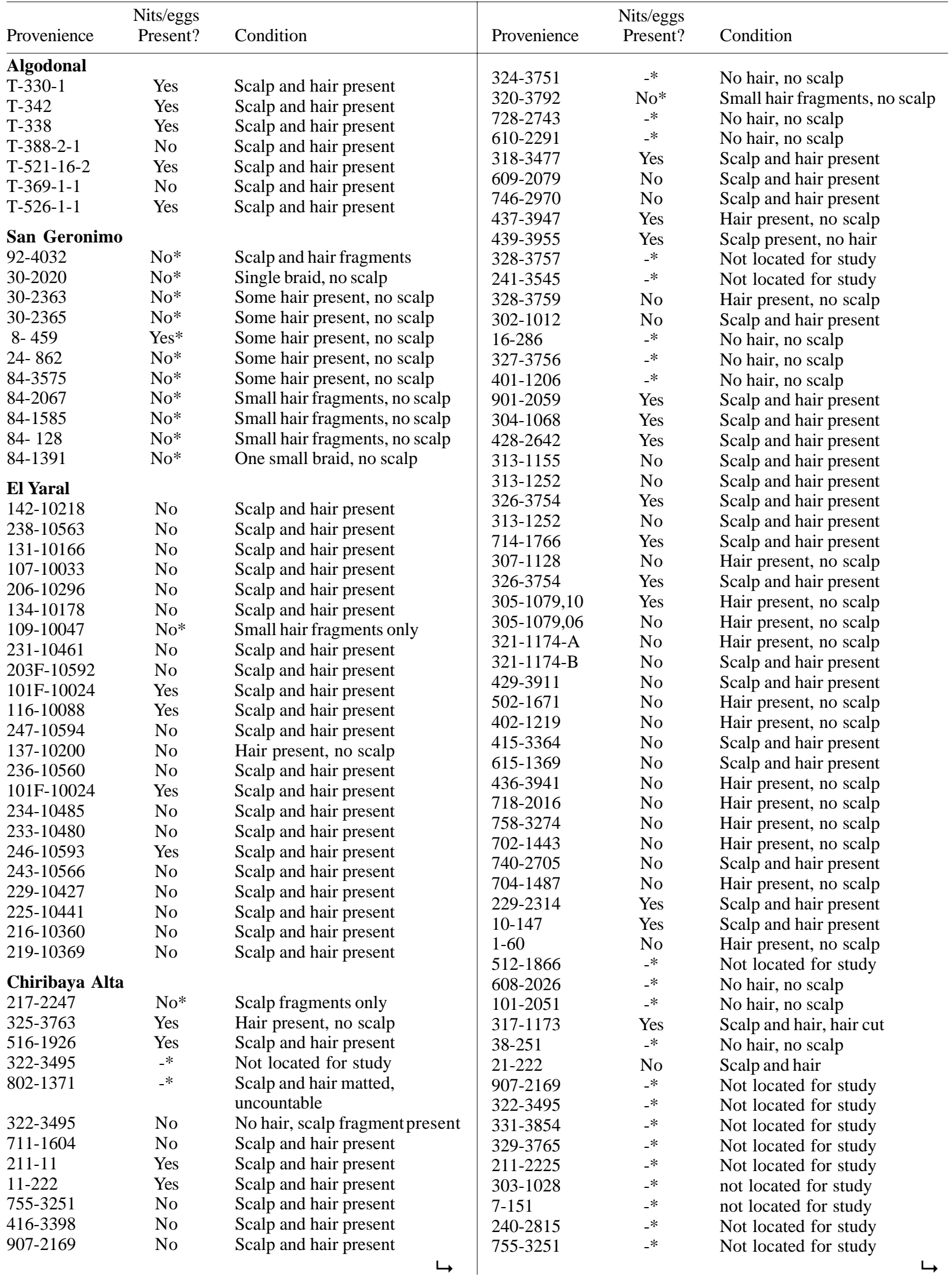




\begin{tabular}{lcl}
\hline Provenience & $\begin{array}{c}\text { Nits/eggs } \\
\text { Present? }\end{array}$ & Condition \\
\hline $1-35$ & $-*$ & Not located for study \\
$763-3468$ & $-*$ & Not located for study \\
$416-3398$ & $-*$ & Not located for study \\
$308-1130$ & No & Hair present, no scalp \\
$804-1383$ & No & Scalp and hair present \\
$14-175$ & Yes & Scalp and hair present \\
$21-246$ & Yes & Scalp and hair present \\
$850-1391$ & Yes & Scalp and hair present \\
$1-120$ & No & Scalp and hair present \\
$30-316$ & No & Scalp and hair present \\
$3-93$ & Yes & Scalp and hair present \\
$17-319$ & Yes & Scalp and hair present \\
$809-1405$ & Yes & Scalp and hair present \\
$705-1502$ & Yes & Scalp and hair present \\
$707-1563$ & $-*$ & No scalp, no hair \\
$407-1304$ & Yes & Scalp and hair present \\
$411-1354$ & No & Scalp and hair present \\
$706-1546$ & No & Scalp and hair present \\
$301-1000$ & No & Scalp and hair present \\
$309-1132$ & No & Scalp and hair present \\
$504-1700$ & Yes & Scalp and hair present \\
$1-1213$ & No & Scalp and hair present \\
$717-1771$ & $-*$ & No scalp, no hair \\
$702-1443$ & No & Scalp and hair present \\
$806-1396$ & Yes & Scalp and hair present \\
$714-1766$ & No & Hair present, no scalp \\
$712-1644$ & No & Hair present, no scalp \\
$704-1487$ & No & Hair present, no scalp \\
$803-1380$ & $-*$ & Not located for study \\
$510-1850$ & $-*$ & Not located for study \\
$412-1364 / 1365$ & No & Hair present, no scalp \\
\hline & & \\
\hline & &
\end{tabular}

cent to the scalp and on the hair away from the scalp, 4 (5\%) had nits/eggs on the hair only, and $9(12 \%)$ had nits/ eggs on the scalp hairs only. In general, there was a tendency for maximum density of nits/eggs to decrease from the scalp to the hair away from the scalp. Twenty (27\%) individuals had fewer nits/eggs on the hair in comparison to the scalp, and $11(17 \%)$ showed more nits/eggs on the hair than on the scalp.

Only seven individuals from Algodonal were available for field analysis. Of these, $5(71 \%)$ were infested with lice. From El Yaral, 22 individuals were available and were sufficiently preserved for analysis. Of these, 4 (18\%) were infested. From Chiribaya Alta, 69 individuals could be studied of which $25(36 \%)$ were infested. Statistical significance in prevalence beyond the 0.05 level is present in El Yaral-Algodonal and Alta-Algodonal comparison $\left(\chi^{2}\right.$ $=9.742,0.005>\mathrm{P}>0.001$ and $\chi^{2}=4.933,0.05>\mathrm{P}>0.025$ respectively). Significance at the near 0.05 level is evident in the El Yaral-Chiribaya Alta comparison $\left(\chi^{2}=3.403\right.$, $0.10>\mathrm{P}>0.05)$. Therefore, louse prevalence is significantly variable between sites (Table III). Sex is a variable that can affect parasite prevalence (Table III). The sites were pooled for this comparison. Of 21 women, 8 (38\%) were infested. Of 18 men, 10 (56\%) were infested. This difference is not statistically different at the 0.05 probability level $\left(\chi^{2}=1.995,0.25>\mathrm{P}>0.10\right)$. There was variation between adults and children. Of 49 subadults from Chiribaya Alta and El Yaral, 12 (24\%) show infestation. Of 43 adults, 19 (44\%) show infestation. The difference is statistically significant beyond the 0.05 confidence inter$\operatorname{val}\left(\chi^{2}=4.907,0.05>\mathrm{P}>0.025\right)$.

The scalp maximum nit/egg densities (column 1 in Table II) are insightful with regard to parasitism at or around the time of death for the individuals under study. We believe that this provides a better idea of how many active louse infestations occurred in the population as opposed to measurements from the hair shafts which infestations represent several months before death. An examination of the distribution of infection (Fig. 1) shows that the louse nits/eggs are not evenly distributed in the human host population. Most individuals were not infected or had small numbers of eggs $/ \mathrm{cm}^{2}$ of scalp. Only a few individuals were heavily infected. For all of the sites, 194 nits/eggs were observed. Of these, 118 (61\%) were observed on $5(6 \%)$ of the mummies. For the site with the largest sample size, Chiribaya Alta, 95 nits/eggs were observed. Of these, $70(74 \%)$ were found on $5(4 \%)$ of the mummies.

The mean maximum louse density also varied per site. The highest mean maximum density of 8.9 nits/eggs $/ \mathrm{cm}^{2}$ was found for Algodonal. The mean maximum density for Chiribaya Alta and El Yaral were 1.7 and 1.73 nits/eggs/ $\mathrm{cm}^{2}$ respectively. The value for all sites was 2.28 nits/ eggs $/ \mathrm{cm}^{2}$. The mean maximum nit/egg density varied between children, men and women. Children had a mean maximum value of 0.8 nits/eggs $/ \mathrm{cm}^{2}$ as opposed to 2.6 for women and 3.5 for men.

The highest concentrations occurred among adults. Among the adults, infestation was limited to 31 (34\%) of 92 people in the sample. Of those people infested, most have a mean maximum scalp value of $1 \mathrm{nit} / \mathrm{cm}^{2}$ or less. We consider a mean maximum density of 5 nits $/ \mathrm{eggs} / \mathrm{cm}^{2}$ or more to represent heavy infestations. Only 8 individuals had heavy infestations which ranged from mean maximum scalp value of 5 nits $/ \mathrm{eggs} / \mathrm{cm}^{2}$ to 22 nits $/ \mathrm{eggs} / \mathrm{cm}^{2}$. Of the total number of nits/eggs counted in the study, $69 \%$ were found on these eight individuals who make up only $9 \%$ of the 92 individuals studied.

\section{DISCUSSION}

In modern parasitology, it is axiomatic that $10 \%$ of the hosts will harbor $70 \%$ of the parasites. These numbers are approximated in the data for El Yaral and Chiribaya Alta. For El Yaral, $84 \%$ of the parasites found in the 2 (10\%) of the most heavily infested mummies. For Chiribaya Alta, $74 \%$ of the parasites were observed on $5(9 \%)$ of the most heavily infested mummies (Figs 1,2). Statistically, these are the most important points that come from this analysis. This demonstrates that it is possible to retrieve paleoepidemiological data from archaeoparasitology studies that approximate the modern world. This is an essential basis for going on to more fine-tuned paleoepidemiological interpretations.

Several basic points can be distilled from Table III. First of all, there is significant variation between the sites in the percentage of mummies infested (Fig. 3). This indicates that the pathoecology of the sites was variable. 
TABLE II

Louse nit counts from specified individuals. Three observations were taken for four categories, scalp maximum density, scalp minimum density, hair maximum density, and hair minimum density. Observations are presented in terms of number of nits/eggs present per $2 \times 2 \mathrm{~cm}$ areas. Chiribaya Culture mummies, Peru

\begin{tabular}{|c|c|c|c|c|c|}
\hline Provenience & Scalp Max & Scalp Min & Hair Max & Hair Min & Sex \\
\hline \multicolumn{6}{|l|}{ Algodonal } \\
\hline T-330-1 & $10 / 12 / 4$ & $0 / 0 / 0$ & $0 / 0 / 0$ & $0 / 0 / 0$ & $?$ \\
\hline $\mathrm{T}-342$ & $1 / 1 / 1$ & $0 / 0 / 0$ & $1 / 1 / 1$ & $0 / 0 / 0$ & $?$ \\
\hline $\mathrm{T}-338$ & $50 / 25 / 58$ & $4 / 10 / 9$ & $8 / 10 / 12$ & $3 / 3 / 1$ & $?$ \\
\hline T-388-2-1 & $0 / 0 / 0$ & $0 / 0 / 0$ & $0 / 0 / 0$ & $0 / 0 / 0$ & $?$ \\
\hline T-521-16-2 & $3 / 2 / 1$ & $0 / 0 / 0$ & $3 / 4 / 5$ & $0 / 0 / 0$ & $?$ \\
\hline T-369-1-1 & $0 / 0 / 0$ & $0 / 0 / 0$ & $0 / 0 / 0$ & $0 / 0 / 0$ & $?$ \\
\hline T-526-1-1 & $6 / 11 / 1$ & $0 / 0 / 0$ & $1 / 2 / 3$ & $0 / 0 / 0$ & $?$ \\
\hline \multicolumn{6}{|l|}{ El Yaral } \\
\hline $142-10218$ & $0 / 0 / 0$ & $0 / 0 / 0$ & $0 / 0 / 0$ & $0 / 0 / 0$ & $\mathrm{~S}$ \\
\hline $238-10563$ & $0 / 0 / 0$ & $0 / 0 / 0$ & $0 / 0 / 0$ & $0 / 0 / 0$ & $\mathrm{~S}$ \\
\hline 131-10166 & $0 / 0 / 0$ & $0 / 0 / 0$ & $0 / 0 / 0$ & $0 / 0 / 0$ & $\mathrm{E}$ \\
\hline $107-10033$ & $0 / 0 / 0$ & $0 / 0 / 0$ & $0 / 0 / 0$ & $0 / 0 / 0$ & G \\
\hline 206-10296 & $0 / 0 / 0$ & $0 / 0 / 0$ & $0 / 0 / 0$ & $0 / 0 / 0$ & $\mathrm{~S}$ \\
\hline 134-10178 & $0 / 0 / 0$ & $0 / 0 / 0$ & $0 / 0 / 0$ & $0 / 0 / 0$ & $\mathrm{~S}$ \\
\hline $231-10461$ & $0 / 0 / 0$ & $0 / 0 / 0$ & $0 / 0 / 0$ & $0 / 0 / 0$ & $\mathrm{~S}$ \\
\hline $203 \mathrm{~F}-10592$ & 0/0/0 & $0 / 0 / 0$ & $0 / 0 / 0$ & $0 / 0 / 0$ & $\mathrm{~S}$ \\
\hline $101 \mathrm{~F}-10024$ & $14 / 12 / 0$ & $0 / 0 / 0$ & $1 / 0 / 0$ & $0 / 0 / 0$ & $\mathrm{~S}$ \\
\hline $101 \mathrm{~F}-10024$ & $1 / 6 / 7$ & $0 / 0 / 0$ & $0 / 0 / 0$ & $0 / 0 / 0$ & $\mathrm{~S}$ \\
\hline $116-10088$ & $24 / 29 / 14$ & $0 / 0 / 0$ & $9 / 1 / 1$ & $0 / 0 / 0$ & G \\
\hline 247-10594 & $0 / 0 / 0$ & $0 / 0 / 0$ & $0 / 0 / 0$ & $0 / 0 / 0$ & $\mathrm{~S}$ \\
\hline $137-10200$ & $0 / 0 / 0$ & $0 / 0 / 0$ & $0 / 0 / 0$ & $0 / 0 / 0$ & $\mathrm{~S}$ \\
\hline 236-10560 & $0 / 0 / 0$ & $0 / 0 / 0$ & $0 / 0 / 0$ & $0 / 0 / 0$ & $\mathrm{~S}$ \\
\hline 234-10485 & $0 / 0 / 0$ & $0 / 0 / 0$ & $0 / 0 / 0$ & $0 / 0 / 0$ & $\mathrm{E}$ \\
\hline $233-10480$ & $0 / 0 / 0$ & $0 / 0 / 0$ & $0 / 0 / 0$ & $0 / 0 / 0$ & $?$ \\
\hline 246-10593 & $2 / 0$ & $0 / 0 / 0$ & $0 / 0 / 0$ & $0 / 0 / 0$ & G \\
\hline 243-10566 & $0 / 0 / 0$ & $0 / 0 / 0$ & $0 / 0 / 0$ & $0 / 0 / 0$ & $\mathrm{~S}$ \\
\hline $229-10427$ & $0 / 0 / 0$ & $0 / 0 / 0$ & $0 / 0 / 0$ & $0 / 0 / 0$ & G \\
\hline $225-10441$ & $0 / 0 / 0$ & $0 / 0 / 0$ & $0 / 0 / 0$ & $0 / 0 / 0$ & G \\
\hline $216-10360$ & $0 / 0 / 0$ & $0 / 0 / 0$ & $0 / 0 / 0$ & $0 / 0 / 0$ & $\mathrm{~S}$ \\
\hline 219-10369 & $0 / 0 / 0$ & $0 / 0 / 0$ & $0 / 0 / 0$ & $0 / 0 / 0$ & $\mathrm{~S}$ \\
\hline \multicolumn{6}{|c|}{ Chiribaya Alta } \\
\hline $325-3763$ & - & - & $3 / 1 / 1$ & $0 / 0 / 0$ & $\mathrm{E}$ \\
\hline 516-1926 & $2 / 3$ & $0 / 0 / 0$ & $2 / 2 / 4$ & $0 / 0 / 1$ & $\mathrm{~S}$ \\
\hline 711-1604 & $0 / 0 / 0$ & $0 / 0 / 0$ & $0 / 0 / 0$ & $0 / 0 / 0$ & $\mathrm{~S}$ \\
\hline $211-2225$ & $10 / 17 / 13$ & $1 / 0 / 0$ & $4 / 5 / 1$ & $0 / 0 / 0$ & $\mathrm{E}$ \\
\hline $21-222$ & $1 / 1 / 1$ & $0 / 0 / 1$ & $0 / 0 / 1$ & $0 / 0 / 1$ & $\mathrm{~S}$ \\
\hline $755-3251$ & $0 / 0 / 0$ & $0 / 0 / 0$ & $0 / 0 / 0$ & $0 / 0 / 0$ & $\mathrm{~S}$ \\
\hline $416-3398$ & $0 / 0 / 0$ & $0 / 0 / 0$ & $0 / 0 / 0$ & $0 / 0 / 0$ & $?$ \\
\hline $907-2169$ & $0 / 0 / 0$ & $0 / 0 / 0$ & $0 / 0 / 0$ & $0 / 0 / 0$ & $E$ \\
\hline $318-3477$ & $0 / 0 / 0$ & $0 / 0 / 0$ & $1 / 2 / 3$ & $0 / 0 / 0$ & G \\
\hline $609-2079$ & $0 / 0 / 0$ & $0 / 0 / 0$ & $0 / 0 / 0$ & $0 / 0 / 0$ & G \\
\hline $746-2975$ & $0 / 0 / 0$ & $0 / 0 / 0$ & $0 / 0 / 0$ & $0 / 0 / 0$ & $E$ \\
\hline $437-3947$ & - & - & $3 / 2 / 1$ & $0 / 0 / 0$ & G \\
\hline $439-3955$ & $6 / 0 / 0$ & $0 / 0 / 0$ & $0 / 0 / 0$ & $0 / 0 / 0$ & $\mathrm{~S}$ \\
\hline $328-3759$ & - & $\longrightarrow$ & $0 / 0 / 0$ & $0 / 0 / 0$ & $\mathrm{~S}$ \\
\hline $302-1012$ & $0 / 0 / 0$ & $0 / 0 / 0$ & $0 / 0 / 0$ & $0 / 0 / 0$ & $\mathrm{E}$ \\
\hline $901-2059$ & $9 / 3 / 3$ & $0 / 0 / 0$ & $22 / 6 / 4$ & $0 / 0 / 0$ & $E$ \\
\hline 304-1068 & $1 / 0 / 0$ & $0 / 0 / 0$ & $1 / 0 / 0$ & $0 / 0 / 0$ & G \\
\hline $428-2642$ & $1 / 0 / 0$ & $0 / 0 / 0$ & $0 / 0 / 0$ & $0 / 0 / 0$ & $\mathrm{~S}$ \\
\hline $313-1155$ & $0 / 0 / 0$ & $0 / 0 / 0$ & $0 / 0 / 0$ & $0 / 0 / 0$ & $\mathrm{~S}$ \\
\hline $313-1252$ & $0 / 0 / 0$ & $0 / 0 / 0$ & $0 / 0 / 0$ & $0 / 0 / 0$ & $\mathrm{~S}$ \\
\hline $326-3754$ & $2 / 7 / 3$ & $1 / 1 / 1$ & $0 / 0 / 0$ & $0 / 0 / 0$ & $\mathrm{~S}$ \\
\hline $313-1252$ & $0 / 0 / 0$ & $0 / 0 / 0$ & $0 / 0 / 0$ & $0 / 0 / 0$ & $\mathrm{~S}$ \\
\hline $714-1766$ & $0 / 0 / 0$ & $0 / 0 / 0$ & $0 / 0 / 0$ & $0 / 0 / 0$ & $\mathrm{~S}$ \\
\hline $307-1128$ & - & - & $0 / 0 / 0$ & $0 / 0 / 0$ & $\mathrm{~S}$ \\
\hline $326-3754$ & $10 / 6 / 7$ & $3 / 5 / 3$ & $0 / 0 / 0$ & $0 / 0 / 0$ & $\mathrm{~S}$ \\
\hline $305-1079,10$ & - & - & $1 / 1 / 1$ & $0 / 0 / 0$ & $\mathrm{E}$ \\
\hline $305-1079,06$ & - & - & $0 / 0 / 0$ & $0 / 0 / 0$ & $\mathrm{~S}$ \\
\hline
\end{tabular}




\begin{tabular}{|c|c|c|c|c|c|}
\hline Provenience & Scalp Max & Scalp Min & Hair Max & Hair Min & Sex \\
\hline 321-1174-A3494 & $0 / 0 / 0$ & $0 / 0 / 0$ & $0 / 0 / 0$ & $0 / 0 / 0$ & $\mathrm{E}$ \\
\hline 321-1174-B3494 & $0 / 0 / 0$ & $0 / 0 / 0$ & $0 / 0 / 0$ & $0 / 0 / 0$ & $\mathrm{E}$ \\
\hline $429-3911$ & $0 / 0 / 0$ & $0 / 0 / 0$ & $0 / 0 / 0$ & $0 / 0 / 0$ & $\mathrm{~S}$ \\
\hline $502-1671$ & - & - & $0 / 0 / 0$ & $0 / 0 / 0$ & G \\
\hline $402-1219$ & - & - & $0 / 0 / 0$ & $0 / 0 / 0$ & $\mathrm{E}$ \\
\hline $415-3364$ & $0 / 0 / 0$ & $0 / 0 / 0$ & $0 / 0 / 0$ & $0 / 0 / 0$ & $\mathrm{G}$ \\
\hline $615-1369$ & $0 / 0 / 0$ & $0 / 0 / 0$ & $0 / 0 / 0$ & $0 / 0 / 0$ & $\mathrm{~S}$ \\
\hline $436-3941$ & $0 / 0 / 0$ & $0 / 0 / 0$ & $0 / 0 / 0$ & $0 / 0 / 0$ & $\mathrm{~S}$ \\
\hline $718-2016$ & $0 / 0 / 0$ & $0 / 0 / 0$ & $0 / 0 / 0$ & $0 / 0 / 0$ & $\mathrm{~S}$ \\
\hline $758-3274$ & $0 / 0 / 0$ & $0 / 0 / 0$ & $0 / 0 / 0$ & $0 / 0 / 0$ & $\mathrm{~S}$ \\
\hline $702-1443$ & $0 / 0 / 0$ & $0 / 0 / 0$ & $0 / 0 / 0$ & $0 / 0 / 0$ & $\mathrm{~S}$ \\
\hline $740-2705$ & $0 / 0 / 0$ & $0 / 0 / 0$ & $0 / 0 / 0$ & $0 / 0 / 0$ & G \\
\hline $704-1487$ & $0 / 0 / 0$ & $0 / 0 / 0$ & $0 / 0 / 0$ & $0 / 0 / 0$ & $\mathrm{~S}$ \\
\hline $229-2314$ & $3 / 5 / 1$ & $0 / 0 / 0$ & $0 / 0 / 0$ & $0 / 0 / 0$ & $\mathrm{~S}$ \\
\hline $10-147$ & $34 / 12 / 16$ & $1 / 1 / 1$ & $1 / 2 / 1$ & $0 / 0 / 0$ & $\mathrm{E}$ \\
\hline $1-60$ & - & 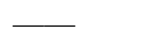 & $0 / 0 / 0$ & $0 / 0 / 0$ & $\mathrm{E}$ \\
\hline $317-1173$ & $14 / 26 / 15$ & $9 / 13 / 2$ & - & - & G \\
\hline $11-222$ & $0 / 0 / 0$ & $0 / 0 / 0$ & $0 / 0 / 0$ & $0 / 0 / 0$ & S \\
\hline $308-1130$ & 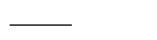 & - & $0 / 0 / 0$ & $0 / 0 / 0$ & $\mathrm{E}$ \\
\hline 804-1383 & $0 / 0 / 0$ & $0 / 0 / 0$ & $0 / 0 / 0$ & $0 / 0 / 0$ & $\mathrm{~S}$ \\
\hline $14-175$ & $1 / 1 / 1$ & $0 / 0 / 0$ & $4 / 3 / 1$ & $0 / 0 / 0$ & G \\
\hline $21-246$ & $0 / 0 / 1$ & $0 / 0 / 0$ & $5 / 5 / 3$ & $0 / 0 / 0$ & $\mathrm{~S}$ \\
\hline $850-1391$ & $1 / 0 / 1$ & $0 / 0 / 0$ & $3 / 4 / 3$ & $0 / 0 / 0$ & $\mathrm{E}$ \\
\hline $1-120$ & $0 / 0 / 0$ & $0 / 0 / 0$ & $0 / 0 / 0$ & $0 / 0 / 0$ & $\mathrm{~S}$ \\
\hline $30-316$ & $0 / 0 / 0$ & $0 / 0 / 0$ & $0 / 0 / 0$ & $0 / 0 / 0$ & $\mathrm{E}$ \\
\hline $3-93$ & $1 / 1 / 1$ & $0 / 0 / 0$ & $0 / 0 / 0$ & $0 / 0 / 0$ & $\mathrm{E}$ \\
\hline $17-319$ & $0 / 0 / 0$ & $0 / 0 / 0$ & $1 / 1 / 1$ & $0 / 0 / 0$ & $\mathrm{G}$ \\
\hline 809-1405 & $2 / 2 / 1$ & $0 / 0 / 1$ & $1 / 0 / 0$ & $0 / 0 / 0$ & $\mathrm{~S}$ \\
\hline $705-1502$ & $1 / 3 / 1$ & $0 / 0 / 0$ & $1 / 1 / 1$ & $0 / 0 / 0$ & $\mathrm{E}$ \\
\hline $407-1304$ & $8 / 17 / 4$ & $2 / 5 / 2$ & $3 / 0 / 3$ & $0 / 0 / 0$ & G \\
\hline $411-1354$ & $0 / 0 / 0$ & $0 / 0 / 0$ & $0 / 0 / 0$ & $0 / 0 / 0$ & $\mathrm{E}$ \\
\hline $706-1546$ & $0 / 0 / 0$ & $0 / 0 / 0$ & $0 / 0 / 0$ & $0 / 0 / 0$ & $\mathrm{~S}$ \\
\hline $301-1000$ & $0 / 0 / 0$ & $0 / 0 / 0$ & $0 / 0 / 0$ & $0 / 0 / 0$ & $\mathrm{E}$ \\
\hline $309-1132$ & $0 / 0 / 0$ & $0 / 0 / 0$ & $0 / 0 / 0$ & $0 / 0 / 0$ & $\mathrm{~S}$ \\
\hline 504-1700 & $0 / 0 / 0$ & $0 / 0 / 0$ & $3 / 1 / 0$ & $0 / 0 / 0$ & G \\
\hline $1-1213$ & $0 / 0 / 0$ & $0 / 0 / 0$ & $0 / 1 / 0$ & $0 / 0 / 0$ & $\mathrm{~S}$ \\
\hline $702-1443$ & $0 / 0 / 0$ & $0 / 0 / 0$ & $0 / 0 / 0$ & $0 / 0 / 0$ & $\mathrm{~S}$ \\
\hline 806-1396 & $1 / 0 / 1$ & $0 / 0 / 0$ & $3 / 2 / 1$ & $0 / 0 / 0$ & $\mathrm{~S}$ \\
\hline $714-1766$ & $0 / 0 / 0$ & $0 / 0 / 0$ & $0 / 0 / 0$ & $0 / 0 / 0$ & $\mathrm{~S}$ \\
\hline $712-1644$ & $\longrightarrow$ & 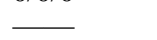 & $0 / 0 / 0$ & $0 / 0 / 0$ & $\mathrm{~S}$ \\
\hline $704-1487$ & - & - & $0 / 0 / 0$ & $0 / 0 / 0$ & $\mathrm{~S}$ \\
\hline $412-1364 / 1365$ & - & - & $0 / 0 / 0$ & $0 / 0 / 0$ & G \\
\hline
\end{tabular}

S: subadult; E: adult female; G: adult male

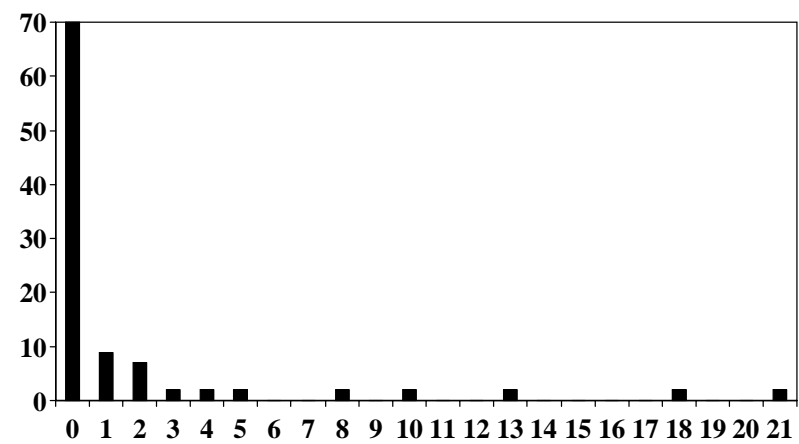

Fig. 1: the distribution of mummies by infection category for Chiribaya Alta. The $\mathrm{X}$-axis is the mean maximum egg/nit counts from the scalp. The $\mathrm{Y}$-axis shows the percentage of mummies that occur in each category. As can be seen, the largest percentage of mummies had no lice nits or eggs.

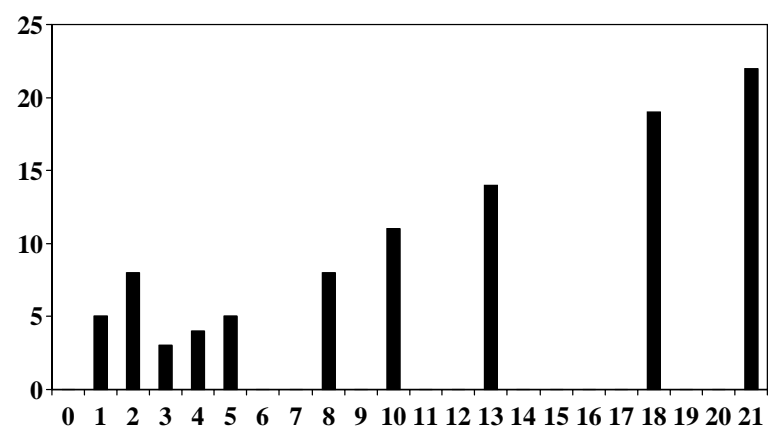

Fig. 2: the percentage of louse observations by infection category for Chiribaya Alta. The X-axis is the mean maximum egg/nit counts from the scalp. The Y-axis shows the percentage of louse egg/nit observations made for each category. As can be seen, the largest percentage of louse observations came from the few mummies that were heavily infected. 
Second, males are more commonly infested than females at all sites. At Chiribaya Alta, adult females are more commonly infested than children. At El Yaral, children are more often infested than women.

Lice are easily transmitted from person to person and crowding results in higher prevalence. Therefore, Pediculus humanus tells us something of the nature of the life conditions between the two villages of Chiribaya Alta and El Yaral. The prevalence per site for P. humanus is plotted in Fig. 3. The prevalence is markedly different between Yaral and Chiribaya Alta. This indicates that the inhabitants of Chiribaya Alta were more crowded and therefore at greater risk of exposure and reexposure than those of El Yaral.

The Chiribaya were certainly host to head lice. The lice must have been a source of considerable discomfort. $P$. humanus is a species of anopluran lice, commonly called sucking lice. The common name refers to their mode of feeding which is by ingesting blood. Their mode of obtaining a blood meal is termed solenophagia. Solenophagic arthropods push their mouth parts directly into blood vessels to obtain blood. The mouth parts are modified into piercing stylets which work in a way analogous to a hypodermic needle. The bites of the louse cause a localized, pruritic response which in turn elicits scratching. The scratching can lead to dermatitis. Secondary infestation could also be a problem. After years of exposure, the scalp becomes thickened and discolored. This condition is commonly known as vagabond's disease. Further examination of Chiribaya crania may show that many individuals suffered from dermatitis.

Individual 802-1371 may reflect the extreme development of pediculosis: plica polonica. In the case of plica polonica, the hair becomes matted with exudate and fungus grows in the mass. Individual 802-1371 exhibited hair that was matted in scab-like material and perhaps was badly effected by lice.

Unfortunately, the hair was so matted on this individual that it was impossible to examine the scalp for the proliferation of lice that accompany plica polonica without destroying the integrity of the specimen.

Men had a higher infestation prevalence than women. This is because men more commonly had elaborate hair styles that covered the scalp in braids (Fig. 4). Shielded by these hair styles, the lice might find more hospitable hosts on men. The men's braided hair was remarkably clean. It is likely that Chiribaya men had more lice for the same reasons as modern girls who are more commonly infested because long, clean hair promotes louse infestation.

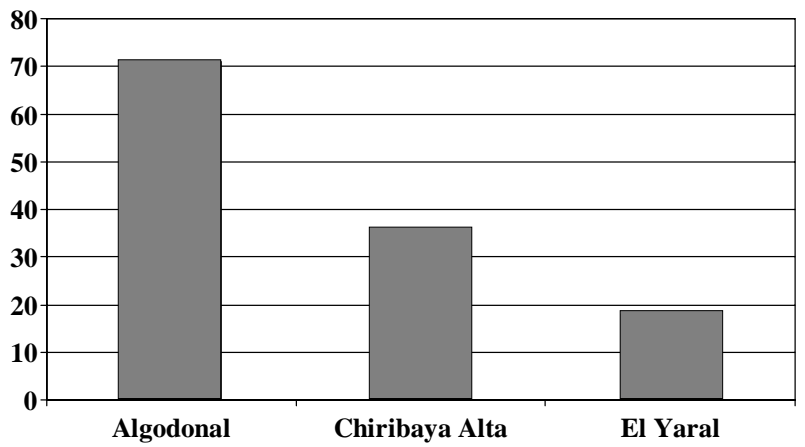

Fig. 3: the percentage of mummies infected from the three main sites, Chiribaya Culture, Peru. As can be seen by this gross comparison, the prevalence of infection varied markedly between the sites.

Considering the annoyance lice must have caused to Chiribayans, they must have had some technological and hygienic tools to minimize louse proliferation. It is possible that the lice were controlled by mutual grooming

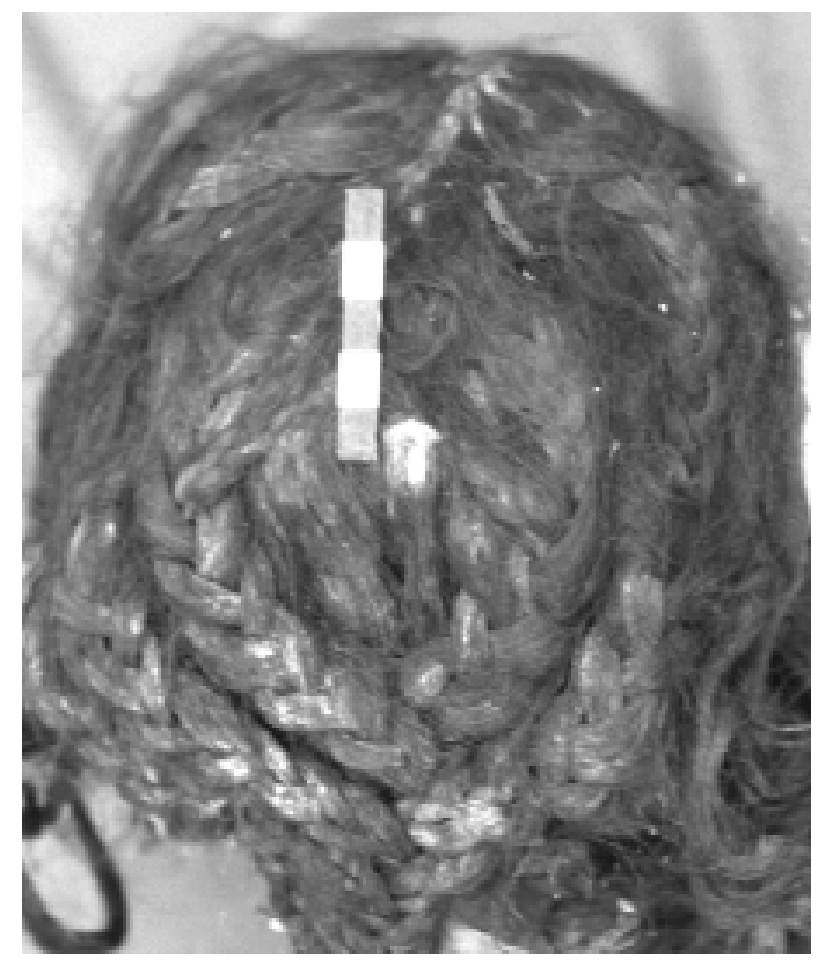

Fig. 4: braided hair styles typical of Chiribaya men, Chiribaya Culture, Peru. Women and children had simple, straight, unbraided hair.

TABLE III

Prevalence of infestation between main study sites. Chiribaya Culture mummies, Peru

\begin{tabular}{lcccc}
\hline Prevalence in $\%$ & Algodonal & El Yaral & Chiribaya Alta & All sites \\
\hline All mummies & $71 \%$ & $18 \%$ & $36 \%$ & $35 \%$ \\
Male mummies & n.a. & $60 \%$ & $62 \%$ & $56 \%$ \\
Female mummies & n.a. & $0 \%$ & $42 \%$ & $38 \%$ \\
Child mummies & n.a. & $14 \%$ & $29 \%$ & $24 \%$ \\
\hline
\end{tabular}


accompanied by eating the lice, as is common among many tribal peoples. Artifactual evidence bears on the question. We noticed comb-like tools buried with some individuals (Fig. 5). These may have been used for weaving. However, the presence of these artifacts shows that the Chiribaya had the technology to make combs. A few individuals had a decreased density of scalp nits/eggs in comparison to hair measurements. This suggests that louse infestation could be controlled and decreased by hygienic measures. Individuals 901-2059, 14-175, 21-46, 850-1391, and 4-1700 show decreasing louse density from the hair to the scalp. This indicates that these individuals were reducing their louse infestations. When louse infestation became extreme, a technique of last resort must have been cutting off the hair. One male, 317-1173, had an amazing density of louse nits/eggs. He did not exhibit the highest maximum density of lice, but he did exhibit a relatively high minimum density. Every square centimeter of scalp had louse nits or eggs. The range of maximum density was $7-13$ nits/eggs $/ \mathrm{cm}^{2}$ with a mean of $9 / \mathrm{cm}^{2}$. The range of minimum densities was $1-6.5$ nits $/ \mathrm{eggs} / \mathrm{cm}^{2}$ with a mean of $4 / \mathrm{cm}^{2}$. This individual must have been suffering severely from louse infection and his hair was shorn off between 1 and 2 inches from the scalp. This individual also suffered from an infestation of the mucocutaneous tissue of the nose and mouth, probably as a result of leishmaniasis. The facial disfigurement of this individual was profound and probably inspired avoidance by other members of the village. Such avoidance and fear is common in areas with endemic leprosy which produces similar soft tissue lesions. In the case of individual 317-1173,

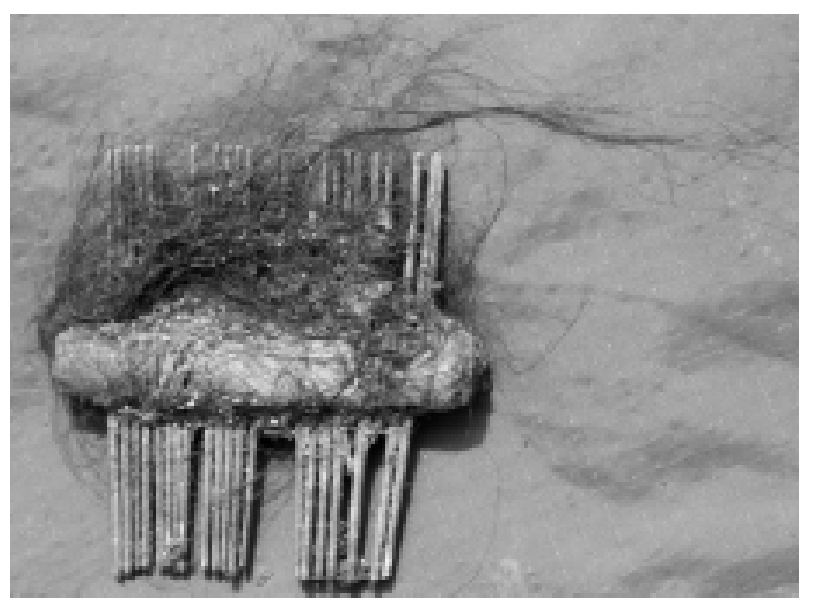

Fig. 5: comb-like tool found in a tomb, Chiribaya Culture, Peru. it appears that the lice proliferated in a weakened individual who may not have been able to gain hygienic aid from anyone else beyond a hair cut. Several individuals show pronounced densities of lice at the scalp with lower densities in the hair. This may indicate a similar proliferation of lice in sick and dying individuals (407-1304, 10147, and 211-2225). Therefore, declining individual health status may have allowed lice to proliferate when individual care could not be easily rendered.

The fact that children were least often infested is interesting. In modern societies, children are most often infested (Mellanby 1942, Ibarra 1989, Mumcuoglu et al. 1990, Ibarra \& Hall 1996, Ibarra et al. 2000). Children from large families are more likely to be infested than children from small families. Child cares, schools, and preschools in the modern world promote social interaction between children and louse infestation. The low prevalence of infestation among Chiribaya children suggest that children were not associated in the same social settings as modern children. The contrast between Chiribaya louse prevalence between the Chiribaya children and modern children highlights the importance of schools and other child-centered social activities in promoting infestation.

Of all the areas of archaeoparasitology, we believe that the study of lice has the greatest potential for providing real epidemiological data regarding past populations. When large numbers of mummies are examined, it is relatively effortless to collect sufficient observations for interpretation. In this study, only San Geronimo had such poor preservation that it could not be used. The poor preservation of mummies from the site of San Geronimo is due to it beach location and association with moisture. Of the remaining three sites, Chiribaya Alta and El Yaral provide the best insights into louse paleoepidemiology due to the relatively large numbers of mummies for which age and sex was determined. The analysis of these mummies shows how aspects of hairstyle and other behavior effected louse distribution among the Chiribaya.

\section{REFERENCES}

Ibarra J 1989. Head lice in schools. Health at School 4: 147-151. Ibarra J, Hall DMB 1996. Head lice in schoolchildren. Arch Dis Child 75: 471-473.

Ibarra J, Fry F, Wickenden C 2000. Treatment of head lice. Lancet 356: 2007.

Mellanby K 1942. Natural population of the head louse (Pediculus humanus capitis: Anoplura) on infected children in England. Parasitology 34: 180-184.

Mumcuoglu KY, Miller J, Gofin R, Adler B, Ben-Ishai F, Almog R, Kafka D, Klaus S 1990. Epidemiological studies on head lice infestation in Israel. Int J Dermatol 29: 502-506. 